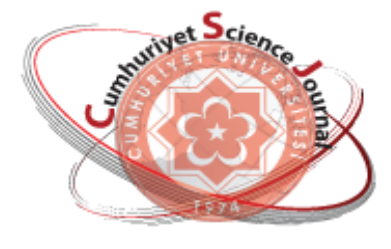

e-ISSN: $2587-246 X$

ISSN: $2587-2680$

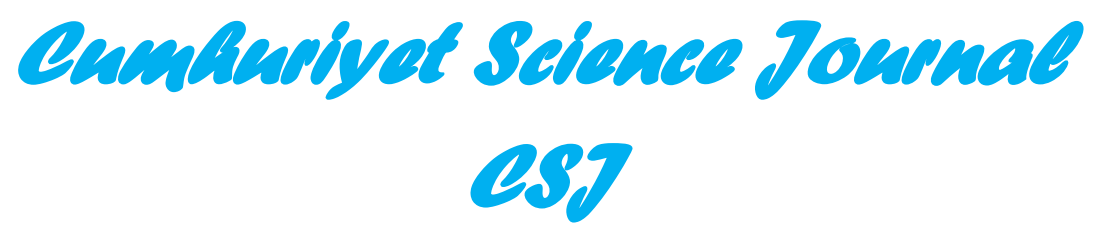

Cumhuriyet Sci. J., Vol.39-2(2018) 531-542

\title{
Flexural Behavior of Graphene Nanoplatelets Reinforced Cross-Ply E- glass/epoxy Laminated Composite Materials
}

\author{
Sakine KIRATLI ${ }^{1 *}$, Züleyha ASLAN ${ }^{1}$

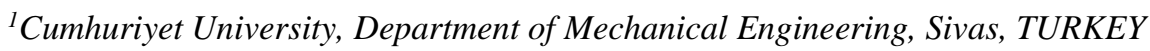

Received: 02.01.2018; Accepted: 17.05.2018

http://dx.doi.org/10.17776/csj.373725

\begin{abstract}
In this study, the effect of graphene nanoplatelets reinforcement on the flexural strength of Eglass/epoxy laminated composite material was investigated experimentally. $\left[0^{\circ} / 90^{\circ}\right]_{3 \mathrm{~S}}$ oriented composite materials with and without graphene nanoplatelets reinforcement were manufactured by using hand lay-up and vacuum bagging method. Graphene nanoplatelets at three different ratios $(0.25,0.5$ and $1 \mathrm{wt} . \%)$ were added to the epoxy. The produced plates were cut with a water jet cutting machine to obtain three-point bending specimens. Then, three-point bending tests were performed according to the ASTM D790 standard. The span between the centers of support cylinders/composite specimen thickness ratio (s/t) was selected as 16 in all the tests. Results indicate that the addition of graphene nanoplatelets to the epoxy matrix increased the flexural strength of the laminated composite material. When the graphene nanoplatelets at ratios of $0.25,0.5$ and $1 \mathrm{wt} . \%$ were added to the epoxy matrix, the flexural strengths increased by $4.32 \%, 12.88 \%$ and $7.03 \%$ respectively.
\end{abstract}

Keywords: Laminated composite, E-glass/epoxy, Graphene nanoplatelets, Flexural strength.

\section{Grafen Nanopul Takviyeli Çapraz Katlı E-cam lifi/Epoksi Tabakalı Kompozit Malzemelerin Eğilme Davranışı}

\begin{abstract}
Özet: $\mathrm{Bu}$ çalışmada grafen nanopul takviyesinin E-cam lifi/epoksi tabakalı kompozit malzemenin esneklik mukavemeti üzerine etkisi deneysel olarak araştırılmıştır. Grafen nanopul takviyeli ve takviyesiz, $\left[0^{\circ} / 90^{\circ}\right]_{3 \mathrm{~S}}$ fiber oryantasyonuna sahip kompozit malzemeler el yatırma ve vakum torbalama yöntemiyle imal edilmiştir. Epoksi içerisine ağırlıkça üç farklı oranda (\% 0.25, 0.5 ve 1) grafen nanopul eklenmiştir. Üretimi yapılan plakalar su jeti kesme makinasıyla kesilerek üç nokta eğme test numuneleri elde edilmiştir. Daha sonra ASTM D790 standardına göre üç nokta eğme testleri yapılmıştır. Destek silindirlerinin merkezleri arasındaki mesafe/kompozit numune kalınlığı oranı (s/t) tüm testlerde 16 olarak seçilmiştir. Elde edilen sonuçlara göre epoksi matris içerisine grafen nanopul eklenmesi, tabakalı kompozit malzemenin esneklik mukavemetini artırmıştır. Epoksi matris içerisine ağırlıkça \% 0.25, 0.5 ve 1 oranlarında grafen nanopul katıldığında esneklik mukavemetinde sırasıyla \% 4.32, 12.88 ve 7.03 'lük bir artış olmuştur.
\end{abstract}

Anahtar Kelimeler: Tabakalı kompozit, E-cam lifi/epoksi, Grafen nanopul, Esneklik mukavemeti.

\section{INTRODUCTION}

Continuous fiber-reinforced polymer composites are used in a wide range of applications, especially in the aviation and space industry because of its advantages such as high specific strength, rigidity and light weight. However, the brittle nature of epoxy matrix composites in particular limits the use of these materials in many applications. 
When any load is applied to the laminated composite material, the load transfer occurs from the matrix material to the fiber. Therefore, any fracture that occurs in the matrix phase causes the delamination damage (separation of successive layers) which significantly decreases the strength of the laminated composite material. The strength of polymer composites can be increased by improving the matrix properties and providing necessary enhancements to the load transfer. For this purpose, nanoparticles have been added to matrix materials in recent years. Nanoparticle reinforcement of the matrix increases adhesion between the fiber and matrix phases [1]. The degree of adhesion between the fiber and matrix phases can be explained with the scanning electron microscopy images from the literature. When comparing the fracture surfaces of non-modified composites and nanocomposites, clear fiber surfaces and smooth fiber pull-out areas have been observed for nonmodified composites while wavy surfaces and epoxy residues have been seen for nanocomposites [2]. Due to the better adhesion between the components of composite materials, it can be said that the load transfer will be better. Thus, properties such as flexural strength, interlaminar shear strength and compressive strength of the laminated composites are improved. Nano-sized particles used for this purpose include carbon nanotubes (singlewalled, double-walled and multi-walled), nanoclays (silica, montmorillonite etc.), nanofibers and graphene nanoplatelets. In addition, the chemical functionalization process of carbon nanotubes and graphene nanoparticles strengthens interfacial linkage by creating a covalent bond between the polymer and nanoparticle [3].

A considerable amount of research in recent years has focused on the determination of the mechanical properties of fiber-reinforced laminated composite materials manufactured by adding carbon nanotubes or nanoclay to epoxy. Rahman et al. [3] used multi-walled carbon nanotubes for E-glass/epoxy composites and investigated the crosslink density and interlaminar shear strength. Chen et al. [4] examined the elastic properties of cross-ply basalt fiber/epoxy composites containing multiwalled carbon nanotubes. To increase the physical properties such as thermal and electrical, single-walled carbon nanotubes were used for polyether ether ketone/glass fiber composites by Ashrafi et al. [5]. Zhou et al. [6] investigated the mechanical behaviors such as fatigue, tensile and flexural and thermal properties for carbon/epoxy composites containing nanoclay. Kanny ve Mohan [7] added nanoclay to the epoxy matrix of glass fiber/epoxy laminates and studied on the static and dynamic behavior. Most studies on graphene nanoplatelets investigated only the properties of the polymer-nanoparticle mixture without using fiber. Chatterjee et al. [8] used both graphene nanoplatelets and multi-walled carbon nanotubes for the epoxy composites. Li et al. [9] added graphene nanoplatelets and multi-walled carbon nanotubes into the epoxy to obtain the epoxy composites. Wang et al. [10] produced nanocomposite by using graphene nanoplatelets and epoxy resin. To obtain the hybrid polymer nanocomposites Le and Huang [11] stirred graphene nanoplatelets and multi-walled carbon nanotubes with epoxy/polyester solutions. According to this literature survey, few studies deal with the effects of graphene nanoplatelets reinforcement on the mechanical properties of continuous fiber-reinforced laminated composites.

Kandare et al. [12] fabricated carbon fiber/epoxy laminated composite materials with and without nanoparticle reinforcement by using hand lay-up and vacuum bagging methods and determined their tensile, compression and bending properties. They also investigated electrical and thermal conductivity properties in the thickness direction. Three different types of nanoparticles (graphene nanoplatelets, silver nanoparticles and silver nanowires) were used in their studies. First, a single type of nanoparticle was stirred into the epoxy at the ratio of $1 \mathrm{vol} \%$. Then, two types of nanoparticles (graphene nanoplateletssilver nanoparticles and graphene nanoplatelets- 
silver nanowires) were stirred into the epoxy at the same time and their mechanical properties were examined. Single type nanoparticle (graphene nanoplatelets) reinforcement increased the bending properties of composites. In the binary combinations, the flexural strength decreased and the flexural modulus increased. Kamar et al. [13] produced S2-glass fiber/epoxy laminated composites by using VARTM (vacuum assisted resin transfer molding) with graphene nanoplatelets added to the epoxy at ratios of $0.1,0.25,0.5$ and 1 wt.\%. They determined bending, Mode-I fracture and lowspeed impact properties. Their experimental results show that the addition of graphene nanoplatelets at the ratio of $0.25 \mathrm{wt} . \%$ caused a $29 \%$ increase in the bending strength of laminated composites. Moreover, the addition of graphene nanoplatelets at a higher ratio provided a minimal increase in bending properties and showed similarity to the unreinforced sample values.

Moriche et al. [14] examined the electrical and mechanical properties of E-glass fiber/epoxy composites which are reinforced graphene nanoplatelets functionalized with $\mathrm{NH}_{2}$. First, they manufactured nanocomposites without using fiber material. They stirred graphene nanoplatelets into the epoxy at ratios of 5, 8, 10 and $12 \mathrm{wt} . \%$. Flexural tests conducted according to the ASTM D790 standard indicated that the fracture deformation of the nanocomposites reduced and the addition of graphene nanoplatelets to the epoxy at the ratio of $12 \mathrm{wt} . \%$ increased the flexural strength and the modulus of elasticity. On the basis of these test results, they produced graphene nanoplatelets reinforced E-glass fiber/epoxy material by using the optimum ratio of $12 \mathrm{wt} . \%$ but could not increase the mechanical properties. Seretis et al. [15] investigated the bending and tensile behavior of graphene nanoplatelets reinforced E-glass fiber/epoxy laminated composites. They conducted an experimental study that involved changing the fabric type and the graphene nanoplatelets ratio. They used graphene nanoplatelets at ratios of 1, 2, 3, 4, 5, 10, 15, 20,
25 and $30 \mathrm{wt} . \%$ for $\left[0^{\circ} / 90^{\circ}\right]_{2}$ oriented laminate and $1,2,3,4,5,10,15$ and $20 \mathrm{wt} . \%$ for $\left[45^{\circ} / 0^{\circ}\right]_{\mathrm{s}}$ oriented laminate. They found that the bending strength increased until the ratio of $5 \mathrm{wt} . \%$ of graphene nanoplatelets for two different fabric types.

Shen et al. [16] investigated the tensile strengths and bending properties of epoxy nanocomposites that contain graphene nanoplatelets at ratios of $0.25,0.5,1$ and $1.5 \mathrm{wt} . \%$. They determined that the tensile and flexural strength of composite materials that contain graphene nanoplatelets at the ratio of $0.25 \mathrm{wt} . \%$ were maximum. They also found that the flexural modulus increased by 1.5 wt.\%. Wang et al. [17] improved the mechanical properties of carbon fiber/epoxy laminated composites by adding graphene nanoplatelets/multiwall carbon nanotube (hybrid reinforcement) into epoxy. They investigated the bending properties, the interlaminar shear strength and the interlaminar fracture toughness of composite materials that contain hybrid reinforcements at ratios of $0.5,1$ and $1.5 \mathrm{wt} . \%$. They found the maximum flexural strength and the maximum interlaminar shear strength at the ratio of $1 \mathrm{wt} . \%$. In addition, the bending modulus and the interlaminar fracture toughness reached their maximum value at the ratio of $1.5 \mathrm{wt} . \%$. Hossain et al. [18] fabricated carbon fiber/epoxy composites by adding graphene nanoplatelets into epoxy at ratios of $0.1,0.2,0.3,0.4$ and 0.5 wt.\% and by using hand lay-up and hot press method. They also investigated the tensile and the bending properties. Findings indicate that the flexural strength and modulus of the composite materials that contain graphene nanoplatelets at the ratio of $0.4 \mathrm{wt} . \%$ was higher than those of the other materials. In addition, the tensile strength and modulus at the same ratio increased significantly.

Most studies either used a single nanoparticle ratio and investigated the different nanoparticles or added only nanoparticles into the epoxy without using fibers to investigate the mechanical properties. Only a few studies investigated continuous fiber-reinforced 
composite materials that contain nanoparticles in their matrix materials. In this research, the effect of graphene nanoplatelets reinforcement at different ratios $(0.25,0.5$ and $1 \mathrm{wt} . \%)$ on the flexural behavior of cross-ply E-glass/epoxy laminated composite materials is examined experimentally. Three-point bending tests were conducted to compare the flexural behavior of laminated composite materials with and without graphene nanoplatelets reinforcement.

\section{MATERIALS AND METHODS}

\subsection{Production of Nanocomposite Materials}

The nanocomposites used in this study were manufactured by hand lay-up and vacuum bagging method in the Composite Material Laboratory of the Department of Mechanical Engineering of Cumhuriyet University. Fiber orientation of E-glass fiber/epoxy laminated composite materials with and without graphene nanoplatelets reinforcement is $\left[0^{\circ} / 90^{\circ}\right]_{3 \mathrm{~s}}$. Bisphenol A-type epoxy F-1564 resin and F3487 hardener were used for the matrix materials (the resin-hardener ratio was 100:34 parts by weight). E-glass fiber is unidirectional and weights $300 \mathrm{~g} / \mathrm{m}^{2}$. The density of epoxy is 1.15 $\mathrm{g} / \mathrm{cm}^{3}$ at $25^{\circ} \mathrm{C}$ and the viscosity is $1200-1400$ $\mathrm{mPa}$.s. The density of the hardener is $1 \mathrm{~g} / \mathrm{cm}^{3}$ at $25^{\circ} \mathrm{C}$ and the viscosity is $30-70 \mathrm{mPa}$.s. The graphene nanoplatelets thickness is $6-8 \mathrm{~nm}$, the average particle diameter is 15 microns and the surface area is $120-150 \mathrm{~m}^{2} / \mathrm{g}$. Graphene nanoplatelets at ratios of $0.25,0.5$ and 1 wt.\% were added to the epoxy. Control specimens (without particles) was produced for comparison.

First, graphene nanoplatelets at the determined proportions were stirred into the epoxy. This mixture was stirred in a magnetic stirrer at 800 rpm for half an hour (Figure 1). Then, the prepared mixture was stirred for another half an hour at $25 \%$ amplitude using a Sonics sonicator to provide a homogeneous distribution (Figure 2). The temperature was controlled by a thermocouple during the mixing process. The beaker was supported by ice bath due to overheating. The hardener was then added to this mixture and stirred with the mechanical mixer for 10 minutes.

The production was implemented by means of a special workbench that has an internal vacuum pump, a heatable aluminum plate and electronic equipment (Figure 3). The mold releaser was spread on this workbench and covered with sealing paste from the edges. One side of the mold releaser was connected with a spiral hose and T-connection. The T-connection was joined to a vacuum pump by means of a transparent hose. Afterwards, the fabrics were spread at the desired number and angle and the mixture was applied by means of a roll (Figure 4). After these processes were completed, peeling fabric, perforated nylon and a blanket were placed on the fabric. Perforated nylon ensures that excess resin and air gaps are transmitted to the blanket. The blanket absorbs the excess resin that is transmitted. The vacuum nylon was used for closing (Figure 5). After the vacuum process, the curing process was conducted at atmospheric pressure at $100^{\circ} \mathrm{C}$ for 2 hours. The average thickness of the produced control specimens and nanocomposite laminates is $4.1 \mathrm{~mm}$ and the volume ratio of the fibers is $47 \%$. 


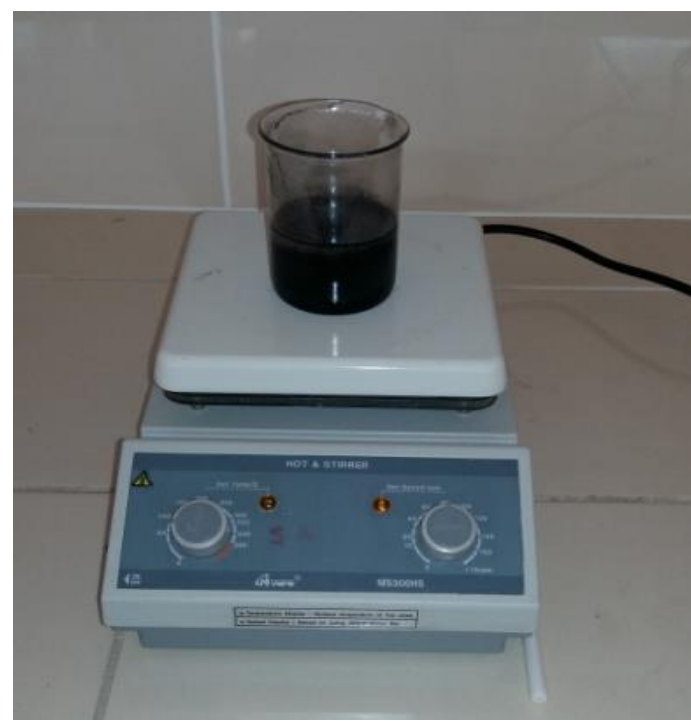

Figure 1. Magnetic mixer.

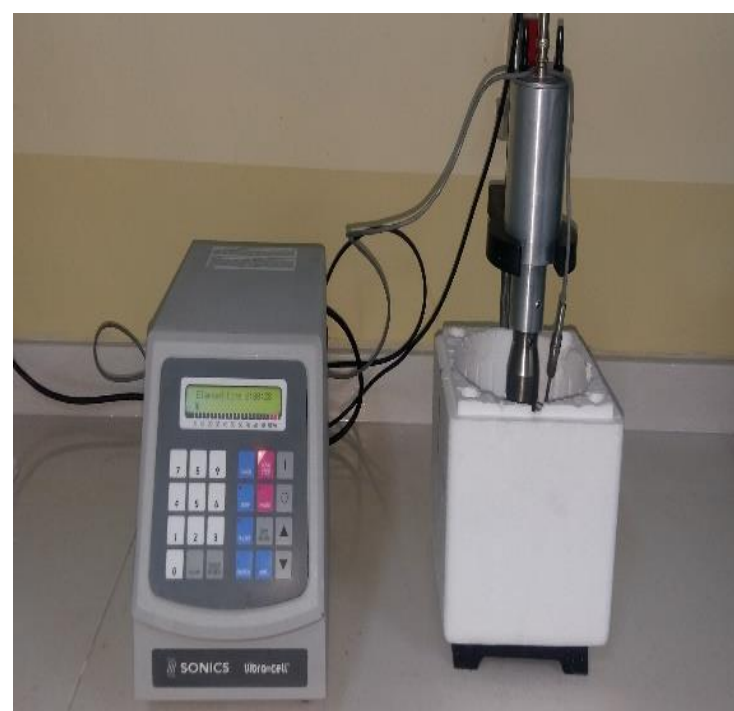

Figure 2. Sonicator.

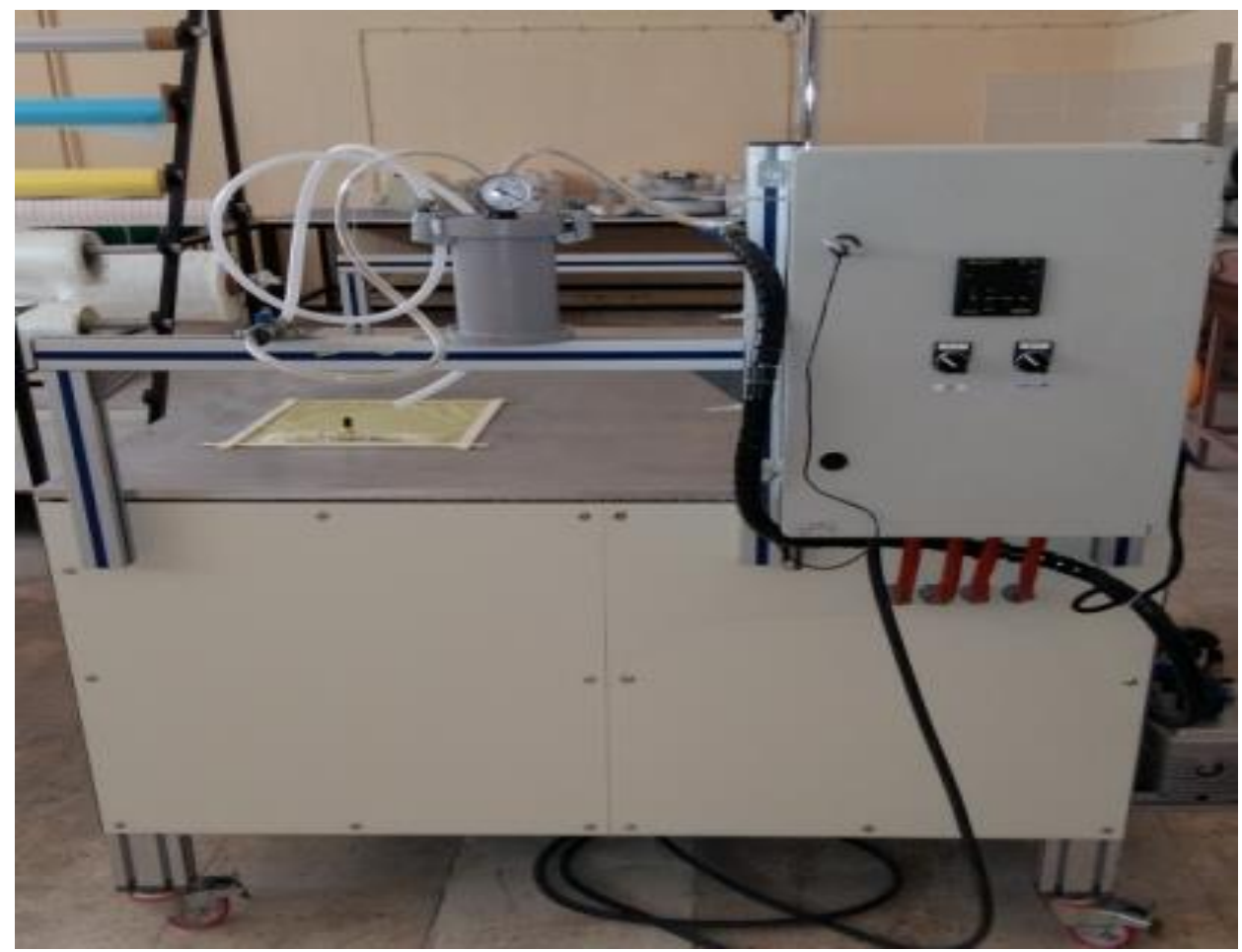

Figure 3. Production workbench. 


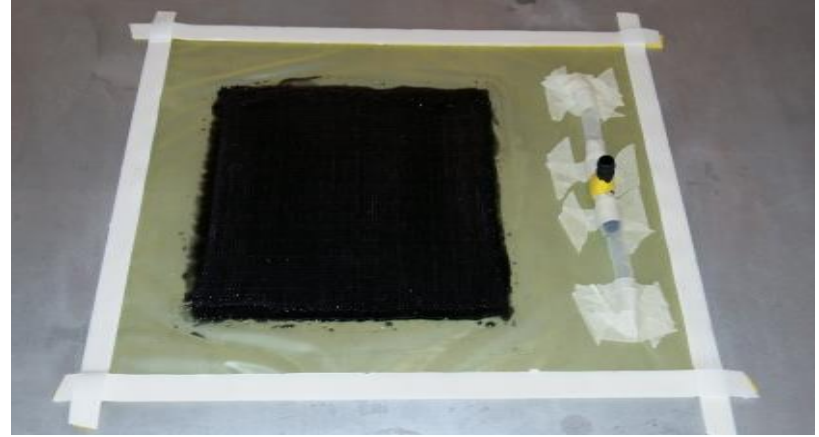

Figure 4. Fabrics wetted with epoxy-nanoparticle mixture.

\subsection{Three-point Bending Tests (ASTM D790)}

Flexural strength tests of the control specimens and the composite specimens that contain graphene nanoplatelets were conducted according to the ASTM D790 standard [19]. In other words, all specimens were subjected to three-point bending tests according to this standard. All tests were performed by using a cylindrical loading head at the middle of the specimen and two cylindrical supports. The width and thickness of the middle of each specimen were measured before the test. The standard recommends an $\mathrm{s} / \mathrm{t}$ ratio of 16:1 (s/t: the span between centers of support cylinders/composite specimen thickness). Thus, the $s / t$ ratio was $16: 1$ in the tests. The lengths of specimen parts overhanging from the supports were set to be at least $10 \%$ of the distance between the centers of support cylinders. The test specimen has a width of $12.7 \mathrm{~mm}$ and a length of $100 \mathrm{~mm}$.

A photograph of the test fixture is shown in Figure 6. Shimadzu universal tensilecompression test machine was used for loading. The velocity of the test machine was $1.8 \mathrm{~mm} / \mathrm{min}$ for all experiments and was determined according to Equation (1) given by the ASTM D790 standard [19].

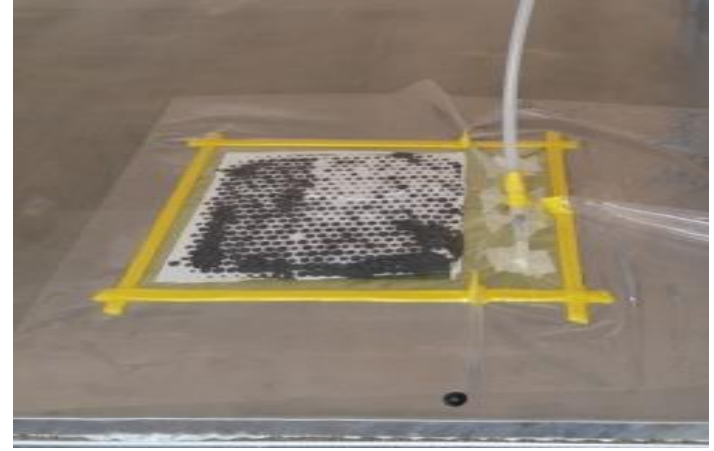

Figure 5. Closing the material with the vacuum nylon and forming the vacuum line.

$\mathrm{R}=\mathrm{ZL}^{2} / 6 \mathrm{~d}$

$\mathrm{R}$ : velocity of the test machine $(\mathrm{mm} / \mathrm{min})$

L: clearance between the centers of the support cylinders $(\mathrm{mm})$

$\mathrm{d}$ : thickness of the composite specimen (mm)

Z: strain ratio of the fibers in the outer face of the composite laminate, $(0.01 \mathrm{~mm} / \mathrm{mm} / \mathrm{min})$.

According to ASTM D790 [19], when fracture occurs or the maximum strain is $5 \%$, the threepoint bending tests are terminated. Five tests were conducted for the control specimen and each composite specimen contained graphene nanoplatelets at different ratios. At the end of the tests, the maximum load values were found and flexural strengths were calculated by using Equation (2) given in the standard [19].

$\sigma_{\mathrm{f}}=3 \mathrm{PL} / 2 \mathrm{bd} \mathrm{d}^{2}$

$\sigma_{\mathrm{f}}$ : flexural strength (from three-point bending test) (MPa)

P: maximum load $(\mathrm{N})$

b: width of the composite specimen (mm) 


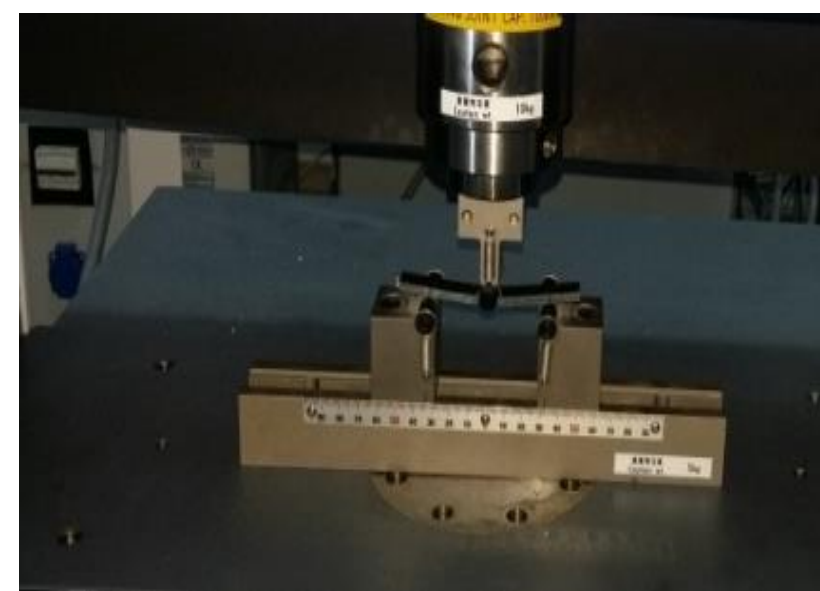

Figure 6. Three-point bending test.

\section{RESULTS and DISCUSSION}

The force-displacement graph obtained by the three-point bending tests on the control

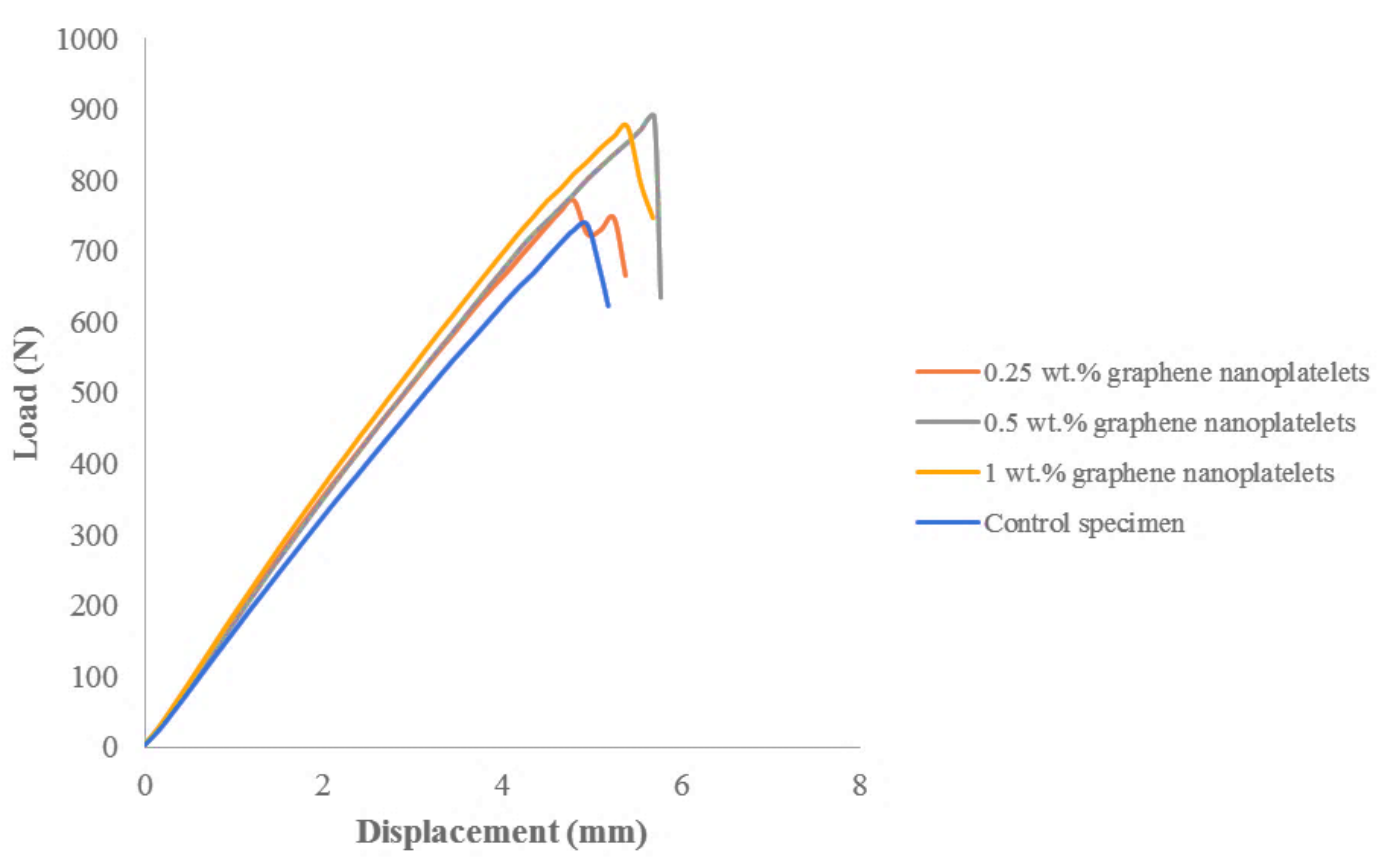

specimen and the composite specimens that contain graphene nanoplatelets are shown in Figure 7. All composite specimens that contain graphene nanoplatelets carry more load than the control specimen. The maximum displacements of the composites that contain graphene nanoplatelets are higher than those of the control specimen. The slopes of lines in the forcedisplacement graph are the nearly same up to the force value of 200-300 N, but when the number of load increases, these slopes start to change. The slope of the line that belongs to the control specimen is lower than that of the composite specimens that contain graphene nanoplatelets. In all tests, a strong sound was heard at the breaking moment and the load-displacement curve decreased rapidly.

Figure 7. Force-displacement graph of the control specimen and the composite specimens containing the graphene nanoplatelets.

The flexural strengths obtained for the control specimen and the composite specimens that contain graphene nanoplatelets according to the ASTM D790 standard are given in Table 1 and Figure 8. The test results indicate that the addition of graphene nanoplatelets to the matrix material of the laminated composites increases the flexural strength. When the graphene nanoplatelets were added to the epoxy matrix at ratios of $0.25,0.5$ and $1 \mathrm{wt} \%$, the flexural strength increased by $4.32 \%, 12.88 \%$ and $7.03 \%$ respectively. The best improvement among the three ratios was obtained at the ratio of $0.5 \mathrm{wt} . \%$. Similar to the flexural strength, the lowest coefficient of variation was found in the composites that contain graphene nanoplatelets at the ratio of $0.5 \mathrm{wt} \%$. Wang et al. [17] increased the flexural strength of the carbon 
fiber/epoxy composite material by $17.5 \%$ by adding graphene nanoplatelets/multiwall carbon nanotubes to the epoxy [17]. Hossain et al. [18] found that the flexural strength of the carbon fiber/epoxy material increased by approximately $19 \%$ with the addition of graphene nanoplatelets to the epoxy. Kandare et al. [13] increased the flexural strength of the carbon fiber/epoxy composite by only $2.11 \%$ by adding the graphene nanoplatelets to the epoxy. Kamar et al. [14] reinforced only the interlaminar region by using graphene nanoplatelets for S2-glass fiber/epoxy composite material and they found that the flexural strength is $29 \%$ higher than that of the control specimen. Seretis et al. [15] increased the flexural strength by approximately $23 \%$ by adding the graphene nanoplatelets to the epoxy for E-glass fiber/epoxy composite materials.

SEM photographs of the damaged composite specimens containing graphene nanoplatelets are seen in Figure 9. While the graphene nanoplatelets appear clearly for the ratio of 0.25 and $0.5 \mathrm{wt} . \%$, the agglomerations are seen at the ratio of 1 wt.\%. Graphene nanoplatelets agglomeration is marked with a yellow box in Figure 9-c. For the ratio of $1 \mathrm{wt} . \%$, the viscosity of the epoxy increased due to the increase in the number of nanoparticles. As a result of the viscosity increase, agglomerations occurred and air bubbles were not able to go out. The voids created by the air bubbles reduced the fibermatrix adhesion and ultimately the flexural strength.

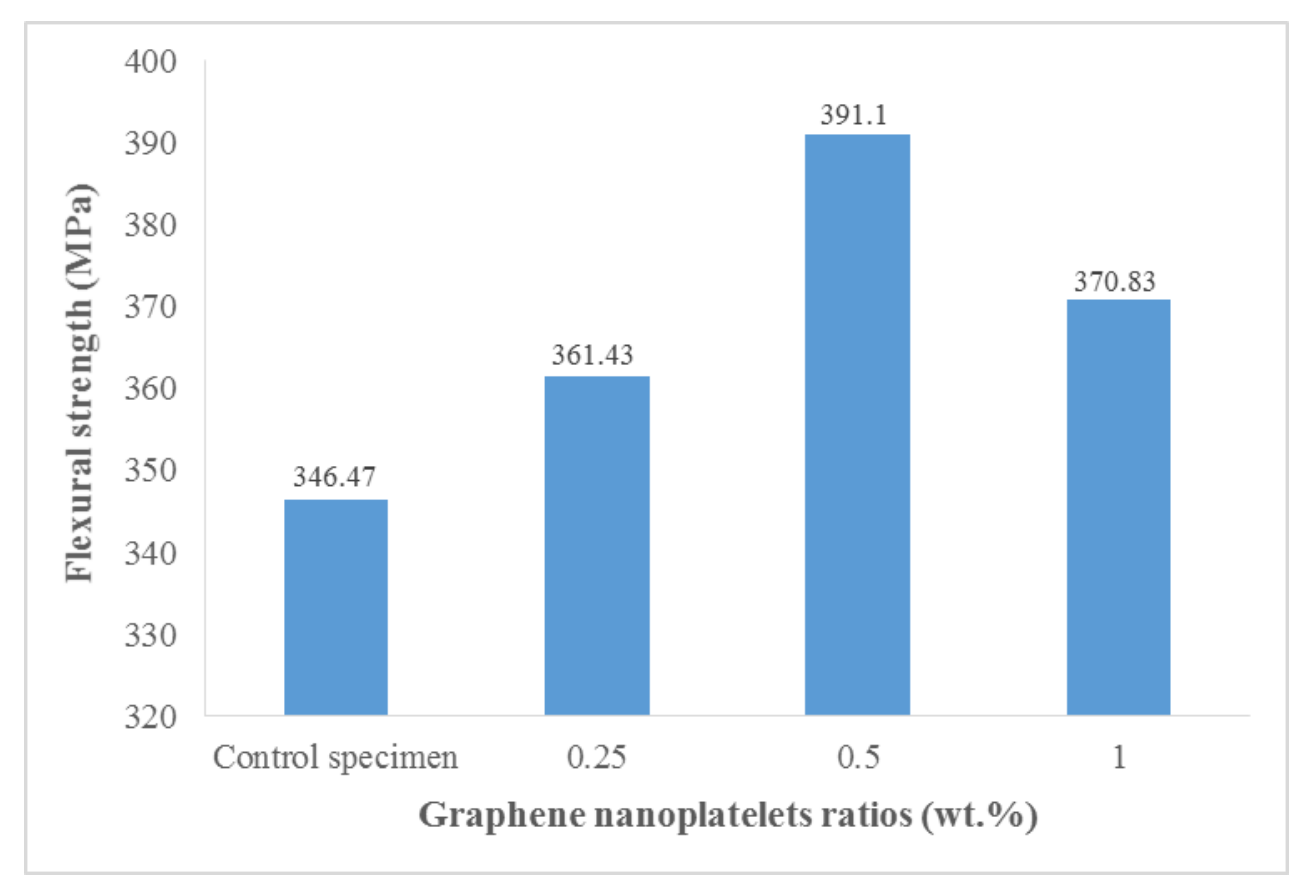

Figure 8. Comparison of the flexural strengths of the control specimen and the composite specimens containing the graphene nanoplatelets. 
Table 1. Three-point bending test results of the control specimen and the composite specimens containing graphene nanoplatelets.

\begin{tabular}{|c|c|c|c|c|c|}
\hline $\begin{array}{c}\text { Graphene nanoplatelets } \\
\text { ratio (wt.\%) }\end{array}$ & Specimen number & $\begin{array}{c}\text { Thickness } \\
\text { mm }\end{array}$ & $\begin{array}{l}\text { Width } \\
\text { mm }\end{array}$ & $\underset{N}{\text { Maximum load }}$ & $\begin{array}{c}\text { Flexural strength } \\
\text { MPa }\end{array}$ \\
\hline \multirow{7}{*}{$\mathbf{0}$} & 1 & 4.02 & 12.7 & 668.939 & 322.68 \\
\hline & 2 & 4 & 12.7 & 690.317 & 336.33 \\
\hline & 3 & 3.92 & 12.69 & 700.792 & 355.79 \\
\hline & 4 & 3.98 & 12.65 & 738.16 & 364.69 \\
\hline & 5 & 4.01 & 12.66 & 725.635 & 352.88 \\
\hline & & & & Mean & 346.47 \\
\hline & & & & Coefficient of variation $(\%)$ & 4.85 \\
\hline \multirow{7}{*}{0.25} & 1 & 4.14 & 12.7 & 731.436 & 332.67 \\
\hline & 2 & 4.07 & 12.71 & 772.397 & 363.20 \\
\hline & 3 & 4.1 & 12.7 & 852.585 & 395.37 \\
\hline & 4 & 4.18 & 12.68 & 850.805 & 380.18 \\
\hline & 5 & 4.16 & 12.71 & 745.885 & 335.72 \\
\hline & & & & Mean & 361.43 \\
\hline & & & & Coefficient of variation (\%) & 7.57 \\
\hline \multirow{7}{*}{0.5} & 1 & 4.11 & 12.7 & 886.822 & 409.25 \\
\hline & 2 & 4.12 & 12.72 & 859.451 & 394.07 \\
\hline & 3 & 4.13 & 12.72 & 865.666 & 395.00 \\
\hline & 4 & 4.2 & 12.77 & 889.826 & 391.07 \\
\hline & 5 & 4.08 & 12.71 & 782.442 & 366.12 \\
\hline & & & & Mean & 391.10 \\
\hline & & & & Coefficient of variation $(\%)$ & 4 \\
\hline \multirow{7}{*}{1} & 1 & 4.25 & 12.71 & 818.825 & 353.10 \\
\hline & 2 & 4.24 & 12.77 & 762.479 & 328.81 \\
\hline & 3 & 4.23 & 12.72 & 876.395 & 381.21 \\
\hline & 4 & 4.1 & 12.72 & 878.366 & 406.68 \\
\hline & 5 & 4.2 & 12.71 & 870.466 & 384.36 \\
\hline & & & & Mean & 370.83 \\
\hline & & & & Coefficient of variation $(\%)$ & 8.15 \\
\hline
\end{tabular}

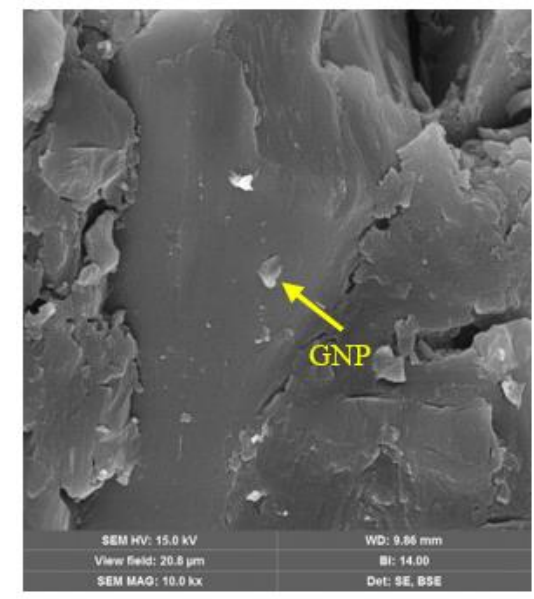

(a)

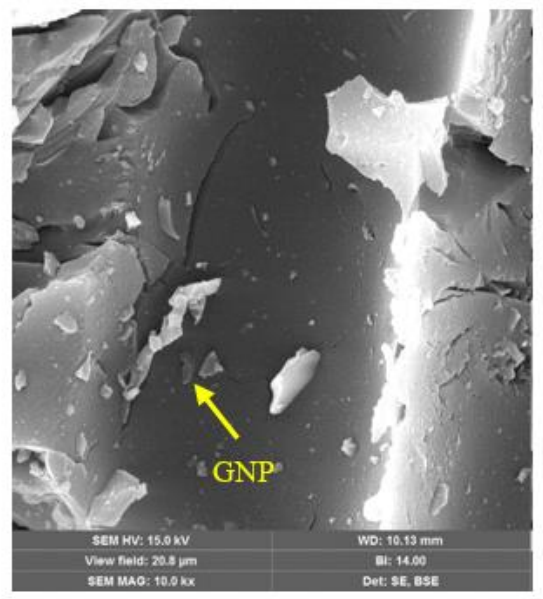

(b)

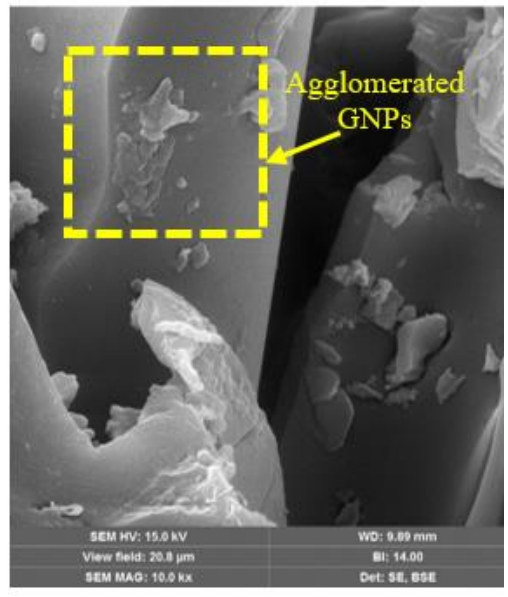

(c)

Figure 9. SEM photographs of the damaged composite specimens containing graphene nanoplatelets at the ratio of a) 0.25 wt. $\%$ b) 0.5 wt. $\%$ c) 1 wt. $\%$ 
Figure 10 and 11 show photographs of the front and back faces of the damaged specimens. For all specimens, the damages appear in the middle of the specimen (under loading cylinder). The damage at the front surface of the control specimen has a more distinctive and regular border than the others do. By contrast, the damage to the composite specimens that contain graphene nanoplatelets is spread over a wider area. The color of the specimens that contain graphene nanoplatelets at the ratio of $1 \mathrm{wt} . \%$ is black due to the high ratio of particles and the damages are invisible to the naked eyes.

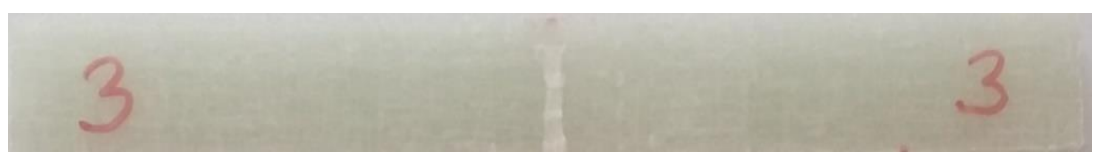

(a)

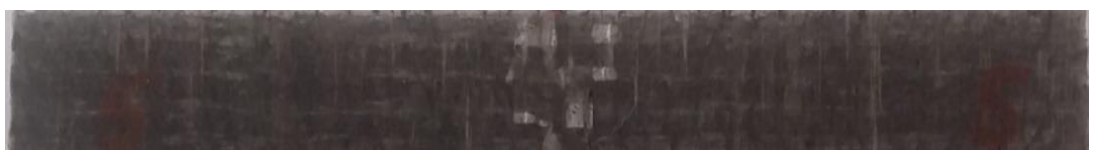

(b)

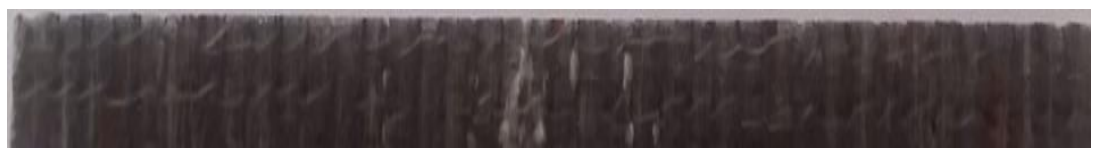

(c)

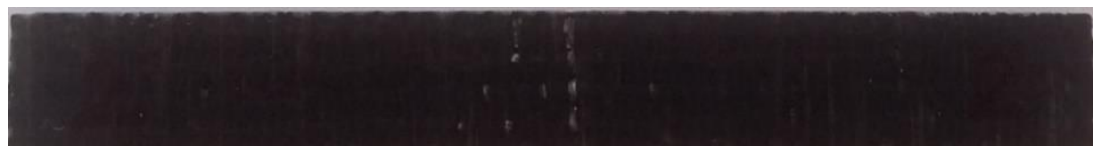

(d)

Figure 10. Front-view photographs of the damaged specimens a) control specimen b) composite containing graphene nanoplatelets at the ratio of $0.25 \mathrm{wt} . \%$ c) composite containing graphene nanoplatelets at the ratio of $0.5 \mathrm{wt} . \%$ d) composite containing graphene nanoplatelets at the ratio of $1 \mathrm{wt} . \%$.

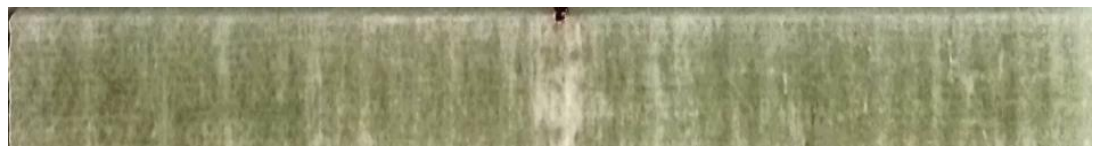

(a)

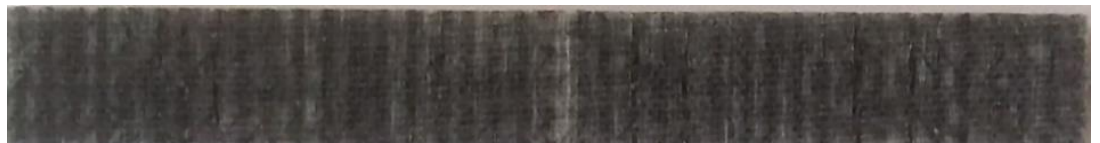

(b)

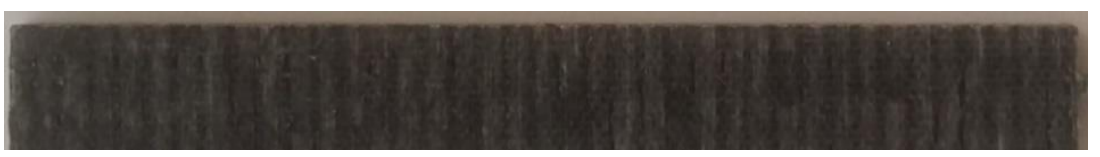

(c)

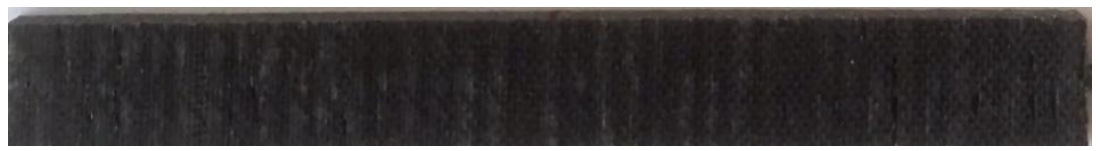

(d)

Figure 11. Back-view photographs of the damaged specimens a) control specimen b) composite containing graphene nanoplatelets at the ratio of $0.25 \mathrm{wt} \%$ c) composite containing graphene nanoplatelets at the ratio of $0.5 \mathrm{wt} \%$ d) composite containing graphene nanoplatelets at the ratio of $1 \mathrm{wt} . \%$. 


\section{CONCLUSIONS}

The flexural behavior of E-glass fiber/epoxy laminated composite materials that contain graphene nanoplatelets at different ratios was determined experimentally. The results obtained by the three-point bending tests are as follows:

- The flexural strength of E-glass fiber/epoxy laminated composites increased with the addition of graphene nanoplatelets to the epoxy matrix. The maximum flexural strength was found in composites that contain graphene nanoplatelets at the ratio of $0.5 \mathrm{wt} . \%$.

- In the three-point bending tests, all specimens that contain nanoparticles carry more load than the control specimen does.

- When graphene nanoplatelets were mixed into the epoxy at the ratio of 1 wt.\%, the viscosity increased and agglomerations occurred, thereby reducing the flexural strength of laminated composites.

\section{ACKNOWLEDGEMENTS}

This work is supported by the Scientific Research Project Fund of Cumhuriyet University under project number M-599.

\section{AUTHOR'S NOTE}

This study was presented as an extended abstract at "the 2nd International Congress on Engineering Architecture and Design" in Kocaeli on May 12-13, 2017.

\section{REFERENCES}

[1]. Taraghi I., Fereidoon A., Zamani M.M. and Mohyeddin A., Mechanical, Thermal and Viscoelastic Properties of Polypropylene/Glass Hybrid Composites Reinforced with Multiwalled Carbon Nanotubes, Journal of Composite Materials, 49-28 (2015) 3557-3566.
[2]. Ulus H., Sahin O.S. and Ave1 A., Enhancement of Flexural and Shear Properties of Carbon Fiber/Epoxy Hybrid Nanocomposites by Boron Nitride Nano Particles and Carbon Nano Tube Modification, Fibers and Polymers, 16-12 (2015) 2627-2635.

[3]. Rahman M.M., Zainuddin S., Hosur M.V., Robertson C.J., Kumar A., Trovillion J. and Jeelani S., Effect of $\mathrm{NH}_{2}$ MWCNTs on Crosslink Density of Epoxy Matrix and ILSS Properties of EGlass/Epoxy Composites, Composite Structures, 95 (2013) 213-221.

[4]. Chen W., Shen H., Auad M.L., Huang C. and Nutt S., Basalt Fiber-Epoxy Laminates with Functionalized Multiwalled Carbon Nanotubes, Composites: Part A, 40 (2009) 1082-1089.

[5]. Ashrafi B., Diez-Pascual A.M., Johnson L., Genest M., Hind S., Martinez-Rubi Y., González-Dominguez J.M., Martinez M.T., Simard B., Gómez-Fatou M.A. and Johnston A., Processing and Properties of PEEK/Glass Fiber Laminates: Effect of Addition of Single-walled Carbon Nanotubes, Composites: Part A, 43 (2012) 1267-1279.

[6]. Zhou Y., Hosur M., Jeelani S. and Mallick P.K., Fabrication and Characterization of Carbon Fiber Reinforced Clay/Epoxy Composite, Journal of Materials Science, 47 (2012) 5002-5012.

[7]. Kanny K. and Mohan T.P., Resin Infusion Analysis of Nanoclay Filled Glass Fiber Laminates, Composites: Part B, 58 (2014) 328-334.

[8]. Chatterjee S., Nafezarefi F., Tai N.H., Schlagenhauf L., Nüesch F.A. and Chu B.T.T., Size and Synergy Effects of Nanofiller Hybrids Including Graphene Nanoplatelets and Carbon Nanotubes in Mechanical Properties of Epoxy Composites, Carbon, 50 (2012) 53805386.

[9]. Li W., Dichiara A. and Bai J., Carbon Nanotube-Graphene Nanoplatelet 
Hybrids as High-Performance Multifunctional Reinforcements in Epoxy Composites, Composites Science and Technology, 74 (2013) 221-227.

[10]. Wang F., Drzal L.T., Qin Y. and Huang Z., Mechanical Properties and Thermal Conductivity of Graphene Nanoplatelet/Epoxy Composites, Journal of Materials Science, 50 (2015) 10821093.

[11]. Le M.T. and Huang S.C., Effect of NanoFillers on the Strength Reinforcement of Novel Hybrid Polymer Nanocomposites, Materials and Manufacturing Processes, 31 (2016) 1066-1072.

[12]. Kandare E., Khatibi A.A., Yoo S., Wang R., Ma J., Olivier P., Gleizes N. and Wang C.H., Improving the Through-Thickness Thermal and Electrical Conductivity of Carbon Fibre/Epoxy Laminates by Exploiting Synergy between Graphene and Silver Nano-Inclusions, Composites: Part A, 69 (2015) 72-82.

[13]. Kamar N.T., Hossain M.M., Khomenko A., Haq M., Drzal L.T. and Loos A., Interlaminar Reinforcement of Glass Fiber/Epoxy Composites with Graphene Nanoplatelets, Composites: Part A, 70 (2015) 82-92.

[14]. Moriche R., Sanchez M., Jimenez-Suarez A., Prolongo S.G. and Urena A., Electrically Conductive FunctionalizedGNP/Epoxy Based Composites: From Nanocomposite to Multiscale Glass Fibre Composite Material, Composites: Part B, 98 (2016) 49-55.
[15]. Seretis G.V., Kouzilos G., Manolakos D.E. and Provatidis C.G., On the Graphene Nanoplatelets Reinforcement of Hand Lay-Up Glass Fabric/Epoxy Laminated Composites, DOI:10.1016/j.compositesb.2017.03.015.

[16]. Shen M.Y., Chang T.Y., Hsieh T.H., Li Y.L., Chiang C.L., Yang H. and Yip M.C., Mechanical Properties and Tensile Fatigue of Graphene Nanoplatelets Reinforced Polymer Nanocomposites, Journal of Nanomaterials, DOI:10.1155/2013/565401.

[17]. Wang P.N., Hsieh T.H., Chiang C.L. and Shen M.Y., Synergetic Effects of Mechanical Properties on Graphene Nanoplatelet and Multiwalled Carbon Nanotube Hybrids Reinforced Epoxy/Carbon Fiber Composites, Journal of Nanomaterials, 50 (2015) 1082-1093.

[18]. Hossain M.K., Chowdhury M.R. and Bolden N.W., Optimized Mechanical Performance of Carbon Fiber-Epoxy Composite Using Amino Functionalized Graphene Nanoplatelets, Proceedings of the ASME International Mechanical Engineering Congress and Exposition, 2015.

[19]. ASTM D790-15, Standard Test Methods for Flexural Properties of Unreinforced and Reinforced Plastics and Electrical Insulating Materials, American Society for Testing and Material, Philadelphia, 2015. 